\title{
Liquid plastic films as a solution in terms of tightness problems and roofs aesthetics improvement - review
}

\author{
Barbara Ksit ${ }^{1}$, Roman Pilch ${ }^{2}$ \\ ${ }^{1}$ Faculty of Civil and Transport Engineering; Poznan University of Technology; Poland \\ barbara.ksit@put.poznan.pl; ORCID:0000-0001-6459-8783 \\ ${ }^{2}$ Faculty of Architecture and Design; University of the Arts Poznan; Poland \\ grafitpilch@wp.pl; ORCID 0000-0002-6780-1350
}

\begin{abstract}
Liquid plastic films are understood as single- or two- or multi-component polymer or polymer bitumen mixtures. Liquid plastic films must meet the requirements for waterproofing insulation, which means, among others, that they must protect the roof from mechanical damage and have resistance to weather conditions. Suitability for use as waterproofing must be confirmed by an ETA (European Technical Assessment) certificate. The article presents the advantages and disadvantages of waterproofing coatings. The application and division of sealing compounds with a brief description of individual solutions are presented. It was also pointed out that the roof aesthetics would be improved due to the use of renovation solutions in the form of plastic films.
\end{abstract}

Keywords: liquid films, waterproofing masses, sealings

\section{Introduction}

Ready-made masses for waterproofing are most often used to secure foundations and basement walls. Many of them are also intended for sealing bituminous roofing materials. They are also used for waterproofing on terraces and balconies. Some of them are also used for insulation in bathrooms and other rooms with high humidity [1]. Because the material adapts to the geometry of the substrate, it allows to incorporate even complex extensions into the surface, such as through elements, dome skylights or roof drains, and adheres to the roof of almost any shape, which prevents water damage. These properties enable sealing architecturally diverse objects with the highest requirements. Existing roofing often suffers damage during assembly work (e.g. air conditioning devices, antenna masts, advertising stands or roof skylights) [2]-[5]. These devices are placed on the bases fixed to the ceilings, which may result in perforations of the roof slope. After completing the assembly work, it is necessary to thoroughly seal the damaged areas to prevent water from entering the building [Fig. 1]. The use of liquid foil in such cases turns out not only convenient, but often the only reliable solution.

Hard-to-reach places, roof outlets with complex shapes, tight spaces between walls, etc are extremely difficult to seal with bitumen roofing. Its thickness, which is usually an advantage, turns into a disadvantage. The ideal material suitable for insulating such places (but also entire roof slopes) are so-called liquid waterproofing foils. 

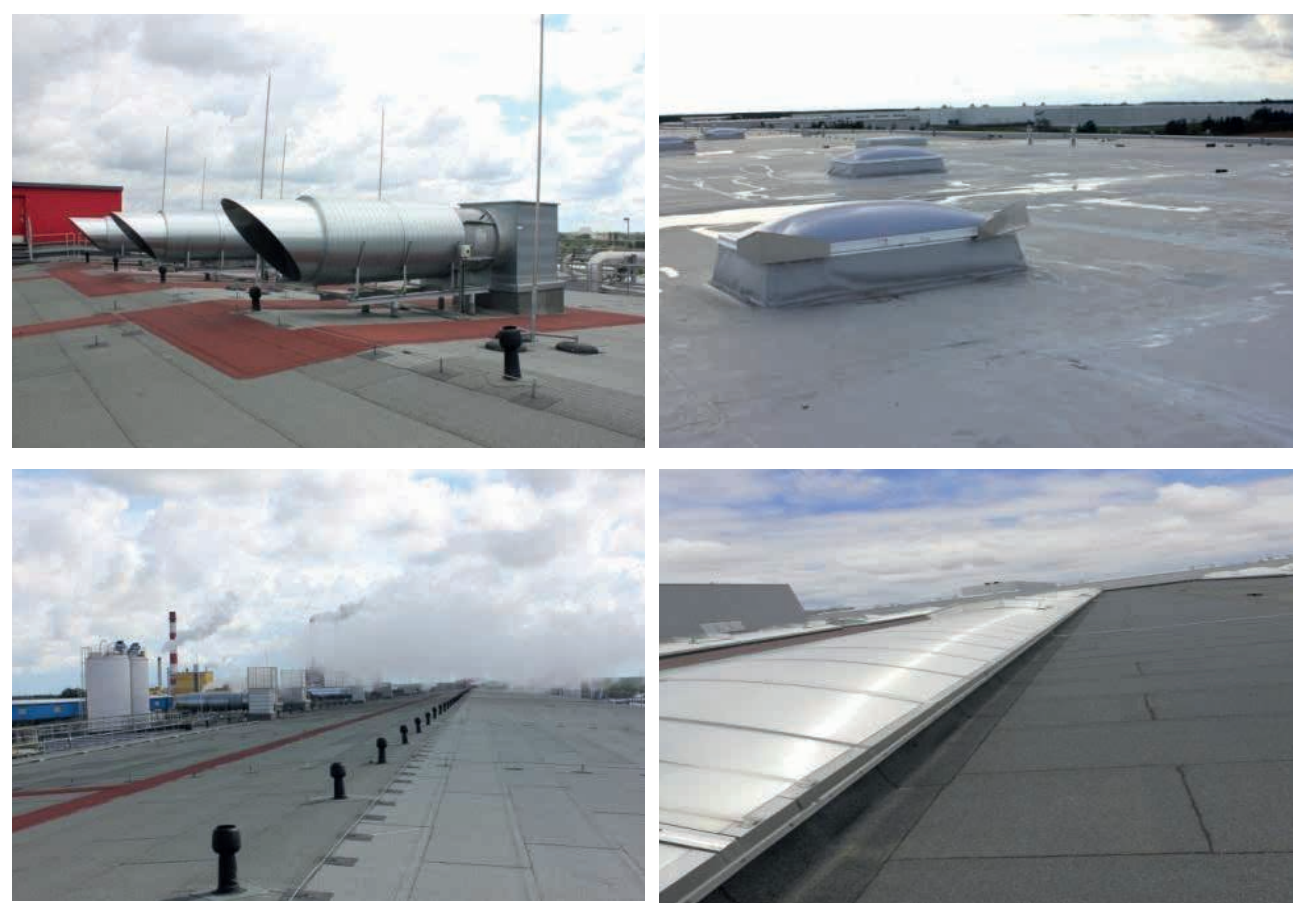

Fig. 1. Crucial areas in flat high-volume rooftops. Source: B. Ksit

\section{Division of materials on the construction market}

On the domestic market, the following sealing materials are used for roof surfaces:

Reactive systems:

- methacrylic resins

- (UP) unsaturated polyesters

- polyurethane resins

Dry systems:

- products based on pure water dispersion

- polymers or copolymers acrylics part of the styrene acrylate group.

Single-component bitumen masses. They are used mainly for maintenance and repairs of bituminous roofing materials, especially roofing felt damage. They can also be used to make independent, seamless bitumen coatings. They contain organic solvents, so they should not come in contact with expanded polystyrene and extruded polystyrene.

Two-component bitumen masses. They are used to obtain a thick film with high flexibility. Two-component bituminous masses are suitable for damp insulation and waterproofing. They are used for all mineral materials. They are recommended for vertical and horizontal insulation. They do not damage the foam, so they can be used to fix foam boards to foundations.

Asphalt-resins masses. They are semi-liquid ready waterproofing compounds with excellent adhesive properties. They are made of moisture insulation, and after applying 3-4 layers - also heavier waterproofing. They are also used for gluing roofing felt and maintenance of bituminous roofing materials. Asphalt-resin compounds are not recommended for insulation 
inside the house. They have a destructive effect on expanded polystyrene and extruded polystyrene. Instead, they penetrate well into the porous structure of the substrate. They are applied with a brush or roofing brush.

Asphalt-rubber masses - can be solvent or dispersion (water-thinnable). The former contain asphalt, artificial rubber (latex), fillers and organic solvents. The dispersion masses contain asphalt emulsion, rubber latex, mineral fillers, water and vulcanizing agents. After application they form a flexible, rubbery coating. They are suitable for vertical and horizontal insulation against moisture and water. They are used indoors and outdoors. Some are enriched with reinforcing fibers, which can be applied to slightly damp substrates. Bentonite clay is also added to some. Styrofoam and other polystyrene products can be glued with dispersion masses. There are also masses of asphalt-rubber available which can be applied at any temperature.

Asphalt-polymer masses have the consistency of a dense paste [12]. They are recommended for vertical and horizontal damp-proof insulation, less often for waterproofing. They can be applied to slightly damp surfaces. Because they form a permanently elastic coating, they can be applied to substrates that are exposed to shrinkage and the formation of scratches and cracks. Asphalt-polymer masses do not damage expanded polystyrene and extruded polystyrene. New are the bitumen-polymer mass containing granules of expanded polystyrene. These granules facilitate even distribution of the mass on the insulated surface.

Asphalt-aluminium masses are liquid masses, they contain an aluminium pigment that tints the surface of the insulated layer silver during desiccation. They are used for regeneration of the bitumen rooftops. The exceptions are tar-based coverings. Thanks to the shiny surface that reflects sunshine, the roof preheats less. They are perfect to protect the slate coverings against dust (dust contains harmful asbestos fibers). The masses are also appropriate to seal in the works connected with tinwork on the roofs. The asphalt-aluminium masses are not appropriate to use indoors because they contain harmful substances.

Asphalt solutions - they are used for priming masonry surfaces, before applying the proper waterproofing layer. Asphalt solutions are also used for gluing roofing sheets and maintenance of corroded concrete surfaces. Some of them are suitable for lightweight moisture insulation. Asphalt solutions are also recommended for corrosion protection of metal structures. They are solvent-ready masses for waterproofing. They should not be used to glue expanded polystyrene and extruded polystyrene, as these materials could then dissolve. Asphalt solutions are flammable substances.

Asphalt emulsions - these are suspension of asphalt molecules in the water [13]. water constitutes up to $50 \%$ of their volume. Predominantly, they are used as a primer for other insulating materials or as light damp-proof courses. Producers offer two kind of such emulsions:

- anionic emulsions - they have a long bonding time - approximately 6 hours. They can be used not only for sealing and priming the bed before the application of the insulating material but also to apply the Styrofoam boards. They can be applied outside the building only if the weather is good, but they can be applied on a wet bed. They are vapour-permeable and odourless.

- cationic emulsions - they bond faster and they can handle even very low temperatures. They are not readily available on the market as few producers offer them.

In addition to asphalt emulsions, latex emulsions are also available on the market. They have a long setting time. They are resistant to chemicals. They can be used for gluing foamed polystyrene. They are suitable for indoor and outdoor use. They are also used for roofing maintenance. They should be applied to dry, possibly slightly moist substrates. 
Polyurethane masses - they are two-component complete masses for hydro-insulation based on polyurethane resins [14]. The polyurethane masses have a semi-liquid consistency. They are suitable for indoor and outdoor use, as horizontal waterproofing and damp-proof courses. They are appropriate for swimming-pools, terraces and balconies insulation. They enable the creation of flexible layers resistant to the chemicals (acids, bases, chlorine, salt and lime solution). Moreover, other than insulating, they fill in small scrapings visible on the surface. They cannot be used to fill in the deeper imperfections of the bed. Bitumen cements - they are complete masses for the hydro-insulation used pro tem to fix the smaller damages visible on the insulation layers.

Liquid polymer foils - they are water dispersion of plastics polymer binder, fillers and modifiers. Except for the water-dilutable foils they are also liquid foils containing organic solvents. The polymer foils are mainly used to create the water resistant protection for ceramic siding. They can be applied to create vertical and horizontal insulation. Some of them can be used only inside the rooms and the others can be applied outside the house. They are applied for insulating the walls and the floors of the bathrooms, terraces and balconies just before a glaze or a terracotta application. They can also be used to glue Styrofoam boards. The liquid foils can be applied on the dry and wet surfaces. Additionally, they fill in any imperfections, cracks and scratches visible on the bed. They create a flexible layer resistant to the chemicals. They hinder concrete corrosion. They are marked by a high resilience to the chemicals and the UV light.

Liquid sealants are the products of a structural chemistry based on resins, for example: a flexible unsaturated polyester resins (UP), elastic polyurethane resins (PUR) and flexible reactive polymethyl methacrylate (PPMA). The liquid sealants are appropriate materials for protection in accordance with the requirements of the European Technical Assessments, they are applied as a liquid material (as their name suggests and they are enhanced with a polyester geotextile.

Single-component sealants are ready to use directly after opening the container, they gel when they come into contact with wet air. Multi-component products always have to be mixed together directly before the application on the bed. There is a chemical reaction in these products when the components blend together. Each of these materials gel and they become homogenous sealings without the connections.

\section{Liquid foils - general characteristics}

\subsection{Advantages and disadvantages}

Liquid plastic films adhere tightly to the sealed surface, without the need for mechanical fixing. They are seamless coatings and accurately fill all kinds of uneven surfaces. In contrast to bituminous felt or plastic membranes, liquid waterproofing films have excellent water vapor permeability. The advantage in this case is that moist surfaces to which a liquid film is applied can dry over time. When sealing the entire roof slope, there is no need to install ventilation stoves. In most cases, it is unnecessary to remove the old coating, because the load on the sealed surface is incomparably small and is usually about $3-3.5 \mathrm{~kg} / \mathrm{m}^{2}$, while the thickness of the finished waterproofing coating (in accordance with the requirements of ETAG 005 for liquid films[6]) is about $2.5 \mathrm{~mm}$.

\section{Advantages:}

- tight filling

- installation on virtually any surface 
- diversified colour palette (reduces heating of horizontal surfaces)

- easy installation in hard to reach places

- very good insulating parameters

- high efficiency

- high level of coverage aesthetics

- high UV resistance - the coating does not age, no cracks after years

- resistance to weather conditions - coating extremely resistant to snow, rain, extreme thermal loads - frost and high temperatures, air pollution, etc.

Disadvantages:

- a small group of qualified fitters

- high price compared to traditional methods

- difficult to remove

\section{The usage of the liquid foils is diverse:}

- a damp-proof protection of the concrete slabs and the walls connected with the ground without exposure to water pressure

- the damp-proof protection of the internal rooms without exposure to water pressure

- the damp-proof protection of the external usable surfaces without an exposure to water pressure

- the damp-proof protection of the concrete slabs and the walls connected with the ground in case of water pressure and permeant waters

- unevenness of the old coating and deformation of the undercoat can be leveled with a flexible and sufficiently thick intermediate layer, e.g. made of polyester or glass fiber

\subsection{Restoration}

Liquid foils are ideal for renovating old coatings and protecting surfaces against environmental degradation. For example, in order to preserve the original stone character of the domes, the still-fresh surface (Kemperol PUR) is sprinkled with quartz sand with a grain size of $0.4-0.8 \mathrm{~mm}$ in natural color.

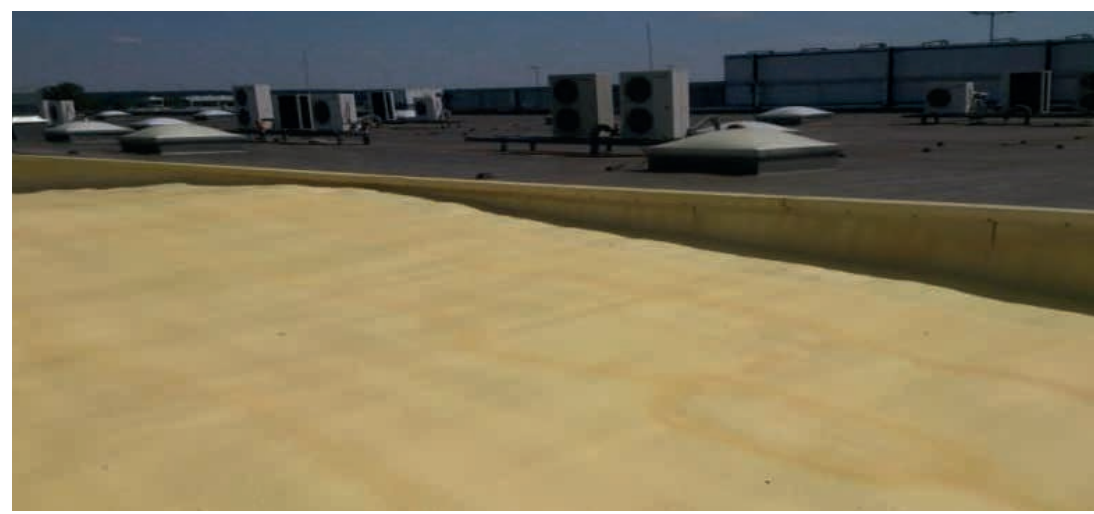

Fig. 2. The roof after the restoration with the use of the plastic foil. Higher level of aesthetics. Source: R. Pilch 


\section{Pro-ecological use - cool roofs}

The Cool Roof Rating Council originated in the United States of America in 1998 (CRRC) - and its main goal is the measurement of the roof features. It is a non-profit organization. [11] The council oversees laboratory tests that are designed to classify products used in roofing. Resins based and polyurethane based masses can be used as a cold coating. The material itself is not ecological, but thanks to its advantages it improves thermal emissivity parameters, i.e. the ability of the surface to return absorbed energy. The modern materials have the emissive ability approximately 0,89 and the reflection factor of approximately 0,78 . In case of the traditional covering the reflection factor for the typical materials used to cover the roofs hovers around 0,10 to 0,25 . The higher factor lengthens the technical lifetime of relevant materials [15], [16].

\section{Summary}

Materials used on construction sites should have ecological parameters [17] - such as dispersion masses. These materials are made in the form of aqueous dispersions. When the agent is applied to the atmosphere, no harmful gases are emitted, only water vapor. The basic material presenting an ecological approach is asphalt rubber. An additional material is decorative and covering mass, which can also serve as maintenance and protection of metal surfaces, especially roofing made of galvanized sheet. Liquid foils can also work as cold roofs, reducing the greenhouse effect of large cities and as environmental load reducers. The use of plastic film materials results in obtaining a smooth surface and a uniform color, resulting in improved aesthetics of the roof surface.

\section{References}

[1] Ksit B., "Dachy balastowe jako przykład przystosowania standardowego dachu do wymogów zimnego dachu" in Proceedings - Forum Nowoczense budownictwo, 02.2018.

[2] Byrdy A., "Pokrycia dachów płaskich z folii z tworzyw sztucznych", Izolacje, vol. 10/2008. http:// riad.usk.pk.edu.pl/ abyrdy/artykuly/Pokrycia.pdf

[3] Francke B., “Część C: Zabezpieczenia i izolacje, zeszyt 1: Pokrycia dachowe”, ITB Warszawa 2019.

[4] Ksit B., Szymczak-Graczyk A., "Rare weather phenomena and the work of large-format roof coverings", Civil and Environmental Engineering Reports, vol. 30(3), 2019, pp. 123-133. https:// doi.org/10.2478/ceer-2019-0029

[5] Ksit B., Monczyński B., Zabezpiecznie dachów płaskich i tarasów. Verlag Dashofer, 2012.

[6] ETAG 005-06: In Form einer flüssigen Versiegelung aufgetragen. Besondere Rückstellungen für flüssige Folien auf Polyurethanbasis.

[7] Adamoski J., Matkowski Z., Materiały do wykonywania warstw hydroizolacyjnych w dachach płaskich. Medium, 2016.

[8] Coster M., Chermant J., "Image analysis and mathematical morphology for civil engineering materials", Cement and Concrete Compolites, vol. 23, 2001, pp. 133-151.

[9] Grębiszewski M., "Gotowe masy do hydroizolacji”. Available: https://budujemydom.pl/ [Accessed: 20 Jan 2020]

[10] DIN EN 1350 1-5 Klassifizierung von Bauprodukten und Bauarten zu ihrem Brandverhalten.

[11] Klatt R., Wytyczne do projektowania i wykonywania dachów z izolacja wodochronna- wytyczne dachów płaskich, DAFA DP 2.01, 2011. 
[12] PN-EN 13707:2013-12. Elastyczne wyroby wodochronne - Wyroby asfaltowe na osnowie do pokryć dachowych - Definicje i właściwości.

[13] PN-EN 13956:2013-06. Elastyczne wyroby wodochronne - Wyroby z tworzyw sztucznych i kauczuku do pokryć dachowych - Definicje i właściwości.

[14] Leszkowski K., Synteza właściwości jonowo przewodzacych materiałów poliuretanowych, Phd dissertation, Faculty of Chemistry, Gdansk Univeristy of Technology, 2011.

[15] Pilch R.,"Charakterystyczne elementy współczesnej sztuki budownictwa" in UNESCO, MAN AND THE BIOSPHERE, URBAN SYSTEM. Zimowski L. ed., Uczelniane Wydawnictwo WSG, Bydgoszcz, 2011.

[16] Laks I. et al., "Hydraulic and legal conditions for buildings in floodplains-case study of Kalisz city (Poland)". IOP Conference Series: Materials Science and Engineering, vol. 471 (2019), 102050. https://doi.org/10.1088/1757-899X/471/10/102050

[17] Trechsel H.R., Moisturecontrol in buildings. ASTM Manual Series, Philadelhia. 1994. 
